Article

\title{
Managing Personal Finance Literacy in the United States: A Case Study
}

\author{
Joshua J. Beck * and Richard O. Garris III \\ Education Department, Robert Morris University, Moon, PA 15108, USA; rogst891@mail.rmu.edu \\ * Correspondence: jjbst321@mail.rmu.edu
}

Received: 30 April 2019; Accepted: 7 June 2019; Published: 12 June 2019

\begin{abstract}
This study investigates the perspectives and impact that personal finance education had on participants in Western Pennsylvania. The researchers begin with a literature review of personal finance courses in the United States (U.S.). The U.S. housing market collapse is also discussed as a key component of the financial crisis that is often overlooked and can be partly attributed to the lack of financial literacy. The findings of this study indicate that participants want personal finance courses offered in K-12 schools and at the collegiate level. They also want personal finance elements to be co-curricular in the K-12 setting. A recommendation based on responses from participants is that co-curricular teaching of personal finance should be tied in with math courses. The participants of this study either have benefited from personal finance lessons themselves or are a strong advocate for the teaching of personal finance in the future. The financial future does also bring worry to the different generations. Generation $X$ is more worried about the financial choices of the upcoming generations, while Millennials and Generation $\mathrm{Z}$ are concerned about the future of the economy and how this will affect them.
\end{abstract}

Keywords: personal finance; financial literacy; financial crisis; United States education; generation X; millennials; generation $\mathrm{Z}$

\section{Introduction}

Increasing financial literacy through increased education and awareness is crucial to the financial future of the United States and its citizens [1-3]. Financial education is vital because it increases financial decision making and knowledge [4-6]. The lack of financial literacy in the United States, in particular, is displayed by the 2008 financial crisis that coincided with the collapse of the housing market [7]. Researchers have differing opinions on what caused the financial crisis. Notable factors include debt rising in the financial sector significantly [8]. Additionally, the deregulation of critical safeguards with derivatives allowed mishandling of this financial instrument, which resulted in risky investments from the financial sector and clouded transparency of these maneuvers to the U.S government [9]. There were also careless ratings, lack of understanding, and underestimated risks with collateralized debt obligation and credit default swaps. Predatory mortgage practices were rampant leading up to the financial crisis. Also, from 1999 to 2008, the financial sector spent 2.7 billion U.S. dollars for federal lobbying, and individual and political committees made more than one billion in campaign contributions [8]. The crisis may have been caused by a lack of ethics amongst financial institutions and the U.S. government. Further compounding the problem was a high number of consumers defaulting on mortgages [10].

Furthermore, the housing market collapse demonstrated that consumers either had no intention of paying their mortgages or lacked the financial knowledge to understand that their mortgages were beyond their means [8]. Some scholars suggest that the housing market crash could have been caused by low levels of financial literacy [11,12]. Moreover, predatory mortgage lending may have contributed to the housing collapse, which could have been prevented with the regulation from The 
Federal Reserve [12,13]. With the missteps of banks in predatory lending and the Federal Reserve not taking action, the housing market crash highlights the low levels of financial literacy amongst U.S citizens, which is further demonstrated by the lack of loan comprehension. The low levels of financial literacy are a cause for concern and a driving force for the purpose of this study.

\section{Review of Related Literature}

\subsection{Student Debts}

Student loan debt in the United States currently stands at 1.5 trillion dollars (U.S. Debtclock.org). Increasing personal finance education may better assist U.S. citizens in understanding and managing this debt $[14,15]$. High school students who have not taken a personal finance course are less likely to take on student debt, and some students and families unknowingly utilize higher interest private loans over federal loans [16]. When the student debt was at 1.3 trillion dollars, seven million borrowers were defaulting [17]. Furthermore, Federal (2016) also found that 11.5 percent of student loans were 90 or more days delinquent [18]. Having more educated people in our country is a positive thing, but what is worrisome is the number of students and families who may mismanage their student loans due to lack of financial comprehension.

\subsection{Financial Literacy}

Poll (2017) surveyed on behalf of the National Foundation for Credit Counseling (NFCC), which measured 1,649 adults from 2013 to 2017 [19]. The findings included 27 percent of adults (ages 35 and up) who invested nothing from their annual income towards retirement. Fifty-five percent of young adults (ages 18-34) indicated they were not confident that they are saving enough for retirement, seven percent of all participants admit they paid a credit card payment late, and eight percent of participants admitted to making a payment less than the minimum required. This survey is critical because it recognizes adults in the workforce currently who need assistance with financial understanding, money management, and retirement planning.

Furthermore, other scholars had similar findings that indicate a lack of knowledge with retirement, investments, and basic economic principles [20,21]. It is worrisome that the current U.S. adult population is having problems grasping critical financial decisions from the economic activity they currently conduct and potentially not teaching their offspring sound financial practices [22]. Even when parents have practiced effective financial choices, many families do not discuss money at all, as it viewed as private [23].

Lusdari and Mitchell (2011) further validate that financial illiteracy is widespread amongst people in the United States [24]. They found in a survey sent to 1,200 U.S. adults, that almost half of the young adults did not know what inflation or risk diversification was. The other notable takeaway from the study was that the higher level of education individuals possess, the better their scores.

Numerous researchers have found that financial literacy in the United States is lacking amongst all age groups $[15,20,25,26]$. From these studies and the fact that every single day consumers are making economic and financial decisions, it is clear that a strong basis of education in personal finance is necessary [1]. Literature also shows that people are willing to take instruction from a professional. From the NFCC survey mentioned above, 80 percent of participants said they would take advice from a professional in regard to personal finance [19]. Kadlec (2013) also mentions that adults think personal finance should be taught in high schools [27].

It appears that the United States realizes the need for financial education by the increase in economic and personal finance courses implemented in the curriculum. However, the problem that still exists is that not nearly enough schools require a personal finance course and that personal the finance curriculum is combined into an economic class as an afterthought [28]. According to Finkelstein, Hanson, Huang, Hirschman, and Huang (2011), the 23 states that have mandated economic courses are only one semester long [29]. In this short amount of time, there is an emphasis on microeconomics 
and macroeconomics, and personal finance is taught as time permits. This fast-paced learning with economics and personal finance is not giving the students an adequate amount of time to learn the material [1].

\subsection{Underqualified Teachers}

In addition to not having enough time to cover the material, a lot of the teachers feel underqualified to teach a personal finance class and are unsure of what pedagogical approach to utilize [30-32]. The findings of some of these studies revealed that teachers felt unprepared with content and pedagogical approaches with personal finance courses, although they recognized the importance of a personal finance class incorporation.

\subsection{Pedagogy}

Research suggests that teachers should be trained on how to teach financial literacy to students. Studies show that active $[33,34]$ and interactive methods have positive effects on students with personal finance concepts $[1,35,36]$. Through a comprehensive literature review of personal finance courses involving the youth, it was noted that the most effective teaching methods are interactive learning experiences with students having the opportunity to partake in hands-on activities [37].

Miller, Hite, Slocombe and, Railsback (2010) indicate that many students have a positive outlook on their future earning power, and most students aspire to surpass or be equivalent to their parent's living standard [38]. This study is beneficial as it links with Mandell and Klein's (2007) findings that indicate that personal finance classes will be most useful to students who are motivated during their instruction [39]. To best motivate students, it is suggested to emphasize why financial literacy is important to their future. It is crucial that personal finance teachers understand these concepts, as it is vital for teachers to feel confident in material and pedagogy to have success [34].

\subsection{Starting Personal Finances with Youth}

Educating our youth about personal finance education is imperative according to the Council of Economic Education [40]. McCormick (2009) and Mandell (2009) echo this statement and emphasize that educating our youth personal finance should be a top priority [41,42]. Alan Greenspan, former Federal Reserve chairman, also stated: "Our children are financially illiterate and unable to inherit the global economy unless we start to educate them in elementary school" [43] (p. 22). Chen and Heath (2012) found that students in elementary and middle school made positive gains when exposed to personal finance lessons [44]. Likewise, Amagir, Groot, Brink, and Wilschut, (2017) found that school-based financial education programs could develop children's and adolescent's financial knowledge and attitudes [45]. There is agreement amongst scholars that financial education should start earlier than high school [37]. Lastly, Morton (2005) mentions that personal finance classes should be a core subject in K-12 schools [46].

\section{Methodology}

The study was conducted via an explanatory case study using face-to-face semi-structured interviews in Western Pennsylvania. Crowe, Creswell, Robertson, Huby, Avery, and Sheki (2011) define case study as an approach that allows in-depth, multi-faceted explorations of complex issues in their real-life settings [47]. This research study gathered real world perspectives from 15 participants. Yin (1981) also discusses a technique used to explain explanatory case study as an accurate representation of the facts, considering alternative explanation of these facts, and concluding with an explanation that is congruent with the facts [48]. That is exactly the scope of this study. Lastly, Creswell (2013) discusses how case study research is a bounded system by time [49]. This study investigates perspectives and impacts from different generations, binding them by their birth year. In vivo coding, a first cycle method, and pattern coding, a second cycle method, were used for this study. In vivo codes attune the researcher into the participant's perspectives $[50,51]$ while pattern coding, groups the codes into 
smaller more meaningful analysis [52]. Six themes were then generated from these codes, which is the recommendation [49]. The explanatory case study approach allowed the researchers to investigate, through a generational lens, the perspectives and experiences of educators, administrators, and students on personal finance education.

The following research questions drove the study:

Research Question 1: What are the perspectives of each generational cohorts in relation to personal finance?

Research Question 2: What is the impact of finance education on the behaviors of individuals in each generational cohort?

\section{Participants}

The participants from this study consisted of 15 members interviewed face-to-face. Six were interviewed from Generation X, three were Millennials, and six were from Generation Z. The participants were from a community college and public and private high schools in Western Pennsylvania. The participants within the community college were two Business Faculty members, one Mathematics Faculty member, one Nursing Faculty member, and one Business and Communication Community College student. From the private high school was a CEO, a Personal Finance Teacher, and two high school students. From the public school, a Principal, an Economics Teacher, Social Studies Teacher, and two high school students were interviewed. The pool of participants consisted of six males, nine females, and all were white/Caucasian. Although scholars disagree on the exact classification of generational cohorts, there is a common consensus on the approximate birth years $[53,54]$. The generational cohorts that the researchers used in this study are represented by the following: Generation X (approximately from 1965-1980), Millennials (approximately from 1981-1995) and Generation Z (approximately from 1996-2011). Table 1 illustrates the participants who served as a representative of their corresponding cohorts and gender.

Table 1. Demographics of participants.

\begin{tabular}{ccc}
\hline Participant & Generation & Gender \\
\hline P1 & Gen X & M \\
P2 & Gen X & F \\
P3 & Gen Z & M \\
P4 & Gen Z & M \\
P5 & Gen X & F \\
P6 & Gen Z & M \\
P7 & Gen Z & F \\
P8 & Gen X & F \\
P9 & Gen X & F \\
P10 & Gen X & F \\
P11 & Gen Z & F \\
P12 & Gen Z & F \\
P13 & Millennial & M \\
P14 & Millennial & M \\
P15 & Millennial & F \\
\hline
\end{tabular}

\section{Results}

The findings suggest distinct themes that were materialized from this data. The six themes are foresight, co-curricular implementation, math infusion, esteemed personal finance, education, and worry. Each theme will be discussed in more depth in the following sections. 


\subsection{Foresight}

The first theme, foresight, was generated because the majority of the participants were prepared financially for the future with investments, retirement, and savings. Participant 9 stated: "I've always contributed to my retirement. Never had to live paycheck to paycheck. Have always had money of some sort." Participant 1 also stated: "What I say to my kids is start putting money away for retirement as soon as you get a job. That is the piece of financial advice that matters. Look down the road." Research does contradict these findings as there is a lack of comprehension of financial tools that prepare people for the future $[20,21]$. The researcher's findings indicate that Generation X had the most financial knowledge, Millennials were not too far behind, lacked some expertise in the investment realm, and Generation $Z$ lacked comprehension of retirement, investing, and what personal finance was but still had foresight regarding future items such as college preparation.

\subsection{Co-Curricular Implementation}

The second theme, co-curricular implementation, was created because every participant would like to see Personal Finance concepts incorporated into other courses, especially starting in younger age groups. Participant 8 said: "I would definitely say that in K-8 personal finance should be co-curricular, incorporated into math classes or social studies, and then I think once you hit 9-12, you could offer a stand-alone course." McCormick (2009) supports this research finding by mentioning the importance of incorporating financial literacy amongst youth and children [41]. McCormick states that teaching personal finance to youth is vital, although it is not championed. Furthermore, participants demonstrated that they were more than comfortable with personal finance incorporated at a young age. Participant 15 mentioned: "My kid (in kindergarten) came home and was counting money so she could save money and buy things. Her guidance counselor told her to do that. I think if they did something even a little more advanced at that age it would kind of get the wheels turning and then build as they get bigger."

\subsection{Math Infusion}

The third theme, math infusion, was evident because it was presented in eight different interviews. Participants discussed how they would like to see Personal Finance material incorporated into Math classes from K-12. Participant 14 mentioned: "I would love to teach personal finance in my math classes. I think so many times people think math is not really useful and personal finance is a great example of when it is." Walstad et al. (2017) also found incorporating personal finance literacy into math to be beneficial [55].

\subsection{Esteemed Personal Finance}

The fourth theme, Esteemed Personal Finance, was discovered in eleven different interviews. Participants mentioned that they thought personal finance should be taught over microeconomics and macroeconomics if they had to choose. The consensus was that personal finance served as an introduction to economics but was also something everyone needed, even those not going to college. Participant 5 stated "Personal finance is the most important because it serves as an introductory point to the others. To go further into economics, you need to understand the basics." Research indicates that economics is currently taught over personal finance in K-12 schools $[1,28,29,56]$.

\subsection{Education}

The fifth theme was education. This theme was created because every participant either had experienced personal finance education and found it to be beneficial or proposed that personal finance should be taught in K-12 or at the collegiate level. Participant 3 stated: "I definitely think more classes should be offered on personal finance since I think it is beneficial to a lot of people who have to do this on their own." Participant 2 mentioned: "I was not taught personal finance in my education, but I 
wish I was. I feel like it would be beneficial in high school as you are looking at student loans, car, and a house at that point." Participant 4 said: "I would push people, if they are in high school still or in college, to seek out personal finance classes." There is literature supporting the validity of teaching personal finance in K-12 and college [2].

\subsection{Worry}

Worry was the last theme created because eleven participants indicated that they were worried about the financial future. An example of this is when Participant 13 said: "There are so many students who do not understand how loans work. Most are not paying off the highest interest rate nor understanding them. Simple things they don't realize until it's too late." Generation X worried about future generations' use of personal finance. Millennials worried about the economy's future, specifically, with regard to investing. This was mentioned because they understood that social security would most likely be eliminated by the time they are retired. Generation $\mathrm{Z}$ was also worried about the economic future.

\subsection{Generational Findings}

Other findings further answer the first research question on the perspectives of each generational cohort in relation to personal finance. Generation $\mathrm{X}$ was very knowledgeable on the subject, and all six participants were able to successfully define personal finance. When defining it, this generation included items such as retirement, investing, saving, mortgage, credit cards, money management, and loans. Retirement, saving, and investments were areas of emphasis from this generation. They found personal finance to be important.

Millennials had two participants indicate that they were knowledgeable on personal finance and one participant did not believe he was very well educated but was able to speak about personal finance to an informed degree. All participants provided a good definition of personal finance and highlighted areas such as material and monetary assets, paying off school loans, car payments, mortgage, savings, credit score, credit cards, investing, and retirement. An area that was highlighted by each participant was establishing appropriate credit. They mentioned how this has helped them save money on purchases such as a car and home. All participants wished they were more educated on retirement and investments but did lean on professionals or their work to guide them through. They believe personal finance education is important and wish they were more educated with regard to investing.

Generation $\mathrm{Z}$ had limited knowledge of personal finance. The majority of the participants struggled to provide an adequate definition of personal finance. Of the participants able to provide a definition, areas of note were taxes, credit, money management, investments, and bank accounts. Despite having limited knowledge and experience, all participants recognized the importance of personal finance. This group of participants appeared to have worry about the future economy, even though they did not fully grasp the concepts.

There were also additional findings that answer the second research question regarding the impact of financial education on the behaviors of individuals in each generational cohort. Generation $X$ participants realized the importance of personal finance and therefore have put to practice what they have learned in education towards planning for retirement and saving money. Since the majority were professors and teachers, the majority of the participants indicated taking additional steps to educate themselves further and find more resources to pass down to students.

Millennials also realize the importance of personal finance for themselves and others. Some have chosen to adopt personal finance by setting financial goals such as paying off specific amounts of debt within a particular time. All millennials demonstrated that they were good at saving money with examples such as this. Two of the three participants have taken steps outside of the classroom to educate themselves because they realized the importance of personal finance. The other participant mentioned that he did not have enough time to educate himself, and that is why it is even more important to teach at the K-12 and collegiate level. 
Generation Z participants provided intriguing results, as the majority of the students admitted to having a lack of financial knowledge, but all still indicated it was very important. The students in high school did show that the focus was more on preparing for college or graduating. Of the four high school students interviewed, the student who was currently in an intro to business course stood out drastically with regard to their personal finance knowledge. Also, the two participants who were in community college did demonstrate more knowledge then those in high school. Those in college mentioned taking steps to educate themselves further. Those in high school recognized the importance of personal finance but thought that they would learn about it when they had to, later on in life, unless it pertained to school loans, which were extremely important to the participants preparing for college.

\section{Discussion}

Themes such as education and math infusion add to the existing research on personal finance [2,55]. Although not every participant quite understood the differences between microeconomics, macroeconomics, and personal finance, the eleven that did, thought that personal finance should be taught out of the three if they had to choose just one. Esteemed Personal Finance could be a crucial finding as literature suggests there is an emphasis on microeconomics and macroeconomics, and personal finance is often left out in the case of K-12 schools [1,28,29]. This shows how important people think Personal Finance is and that schools should consider this development when deciding on course selection. There also is existing literature that indicates that teaching the youth personal finance is important $[35,37,44]$. However, this study found a new development that people place emphasis on the use of co-curricular implementation with personal finance and want this to be a focus of the youth. This finding could be beneficial as schools would not have to cut courses in order to add financial concepts into the curriculum. Foresight also indicates that everybody has the future in mind, but planned preparations depend on the age. Worry is also a new finding to add to the personal finance research and also a topic that could be explored in further research.

This study also added new developments amongst perspective and impacts from Generation X, Millennials, and Generation Z. It was evident that the more education one had, the more knowledge they had of financial concepts. This finding is also supported in the literature [24]. It was also intriguing that each generation had different foresight and different worries. The findings of this study add to personal finance literature and established building blocks for future studies which may use larger sample sizes and concepts explored in this study. The notion that participants want co-curricular aspects of personal finance classes in other courses is something K-12 schools and teachers should consider when developing lesson plans and a curriculum. K-12 schools and higher education should also look at the courses they offer and take into consideration implementing a personal finance course. Furthermore, the results of this study provide insights into what financial areas are essential and a worry to each generation. These generational findings are important as they help further identify what areas of personal finance are worthy of teaching and at what age to focus on particular concepts. The worries presented also help further fine-tune areas of teaching with specific ages and identify areas of importance within that generation and the generation ahead.

\section{Conclusions}

In summary, this study investigated different perspectives on personal finance and the impact of personal finance on different generations. Based on a review of related literature, it is apparent that personal finance courses can be beneficial, and the lack of financial literacy amongst U.S. citizens is low and often overlooked [26]. The findings of this study demonstrated a correlation between age, education, and personal finance knowledge. This study also revealed that a large portion of participants have foresight when it comes to their finances. This was especially true with the Millennial and Generation $X$ participants, who noted that they prepare for the future by saving, investing, and creating appropriate budgets. Generation $\mathrm{Z}$ also reported foresight, but it was more specifically based on school loans and things in their immediate future. The results of this study build on the existing 
literature showing that people think personal finance should be co-curricular in schools but has a new development with the emphasis on youth. This study also recommended the incorporation of personal finance concepts into math classes, as the participants saw easy integration with the course material. Additionally, this study found that participants thought personal finance material should be taught over economics material if they had to choose between the two. All participants of this study thought personal finance was beneficial and should be taught in K-12 or at the collegiate level. Moreover, worry was presented from the participants at varying levels. Older generations reported worry based on how younger generations managed their money. Younger generations, on the other hand, were more worried about the future of the economy going forward, especially with the realization that social security funds may not be available at the point of retirement. Overall, this study is beneficial as it adds to the existing personal finance literature and presents new information on the importance of personal finance over economics, the emphasis on teaching the youth financial concepts, and the different areas of worry and foresight for each generation.

To conclude, there are a lot of free resources available regarding personal finance and classroom assistance. There is the Financial Fitness for Life (FFL), which is built for K-12. It has visuals, activities, and lessons that may be useful [57]. There is literature that states that the FLL increased students' financial knowledge [5,58]. Another free resource is the National Endowment for Financial Education (NEFE), which is more for Grades 8-12 but has relevant financial literacy tools for a variety of ages [59]. The Federal Reserve also created federalreserveeducation.org, which is a website built for educators and allows free, easy access to all of the Federal Reserve's educational resources in one location [60]. Jacob (2002) provides a resource for evaluating the effectiveness of a personal finance educational program. In addition to the evaluation, the article offers a lengthy list of national financial literacy programs [61].

\section{Limitations and Future Recommendations}

The limitations of this study were the number of participants that represented each generational cohort. There were fruitful findings within the purposive sample, however, due to the small size, the results are limited in generalizability, and are not applicable to larger populations, although they provide valuable context for a larger-scale study. Another limitation was that Generation X was mostly represented by administrators, professors, and teachers and therefore, had a larger degree of experience or education within the realm of personal finance. This may have contributed to their demonstrated knowledge of personal finance. In the same vein, the Millennial participants were also professors and teachers. This could have impacted their financial knowledge, although none of them were teachers in the realm of business. The study could have been improved if there had been a larger selection of random people with less education and experience. This would generate a more random sample that would allow for more comparisons.

The first recommendation would be to conduct a similar study with the use of a broader sample to see if it produced similar findings and trends. It is also a recommendation to revisit this study in several years to see if the perceptions of generations have changed and to compare the knowledge of the new, forthcoming generation with the results of Generation $\mathrm{Z}$ in this study.

Author Contributions: Each author contributed 50 percent to this publication.

Funding: This research received no external funding.

Conflicts of Interest: The authors declare no conflict of interest.

\section{References}

1. Dyer, S.P.; Lambeth, D.T.; Martin, E.P. Effects of multimodal instruction on personal finance skills for high school students. J. Sch. Educ. Technol. 2016, 11, 1-17.

2. Hite, N.G.; Slocombe, T.E.; Railsback, B.; Miller, D. Personal finance education in recessionary time. J. Educ. Bus. 2011, 86, 253-257. [CrossRef] 
3. Franklin, D. Teacher Involvement in Implementing State Personal Finance Mandates. Ph.D. Thesis, Indiana State University, Terre Haute, Indiana, 2015.

4. Danes, S.M.; Huddleston-Casas, C.; Boyce, L. Financial planning curriculum for teens: Impact evaluation. J. Financ. Couns. Plan. 1999, 10, 26-39.

5. Harter, C.L.; Harter, J.F.R. Assessing the effectiveness of financial fitness for life in Eastern Kentucky. J. Appl. Econ. Policy 2009, 28, 20-33.

6. Hilgert, M.A.; Hogarth, J.M.; Beverly, S. Household financial management: The connection between knowledge and behavior. Fed. Reserve Bull. 2003, 89, 309-322.

7. Campbell, J.L. The U.S. financial crisis: Lessons for theories of institutional complementarity. Socio-Econ. Rev. 2011, 9, 211-234. [CrossRef]

8. Financial Crisis Inquiry Commission \& United States. The Financial Crisis Inquiry Report, Authorized Edition: Final Report of the National Commission on the Causes of the Financial and Economic Crisis in the United States; Public Affairs: New York, NY, USA, 2011; pp. 1-623.

9. Acharya, V.V.; Richardson, M. Restoring Financial Stability: How to Repair a Failed System; John Wiley \& Sons: Hoboken, NJ, USA, 2009; pp. 1-381.

10. Claessens, S.; Kodres, L.E. The Regulatory Responses to the Global Financial Crisis: Some Uncomfortable Questions; International Monetary Fund: Washington, DC, USA, 2014; pp. 1-29.

11. Dinwoodie, J. Ignorance is not a bliss: Financial illiteracy, the mortgage market collapse, and the global economic crisis. Univ. Miami Bus. Law Rev. 2010, 18, 181-206. [CrossRef]

12. Frank, H. The Financial crisis of 2008: A clarion call to include economic policy and financial illiteracy on public administration's intellectual radar screen. Adm. Theory Prax. 2009, 31, 409-416. [CrossRef]

13. Taylor, M.W.; Arner, D.W. Global regulation for global markets? In Lessons from the Financial Crisis: Causes, Consequences, and Our Economic Future; Kolb, R., Ed.; Wiley: Hoboken, NJ, USA, 2010; pp. 383-391.

14. Lusardi, A.; Tufano, P. Debt literacy, financial experiences, and overindebtedness. J. Pension Econ. Financ. 2015, 14, 332-368. [CrossRef]

15. Boatman, A.; Evans, B.J. How financial literacy, federal aid knowledge, and credit market experience predict loan aversion for education. Am. Acad. Political Soc. Sci. 2017, 671, 49-68. [CrossRef]

16. Baum, S.; Schwartz, S. Student Aid, Student Behavior, and Educational Attainment; George Washington University: Washington, DC, USA, 2013; pp. 1-26.

17. Dynarski, S. How to and how not to manage student debt. The Milken Institute Review. Available online: https://www.milkenreview.org/articles/how-to-and-how-not-to-manage-student-debt (accessed on 1 March 2019).

18. Federal Reserve Bank of New York. Quarterly Report on Household Debt and Credit; Federal Reserve Bank: New York, NY, USA, 2016; pp. 1-33.

19. Poll, H. The 2017 Consumer Financial Literacy Survey, National Foundation for Credit Counseling. Available online: https://nfcc.org/wp-content/uploads/2017/03/NFCC_BECU_2017-FLS_datasheet-with-key-findings. pdf (accessed on 1 March 2019).

20. Clark, R.L.; Morrill, M.S.; Allen, S.G. The role of financial literacy in determining retirement plans. Econ. Inq. 2012, 50, 851-866. [CrossRef]

21. Lusardi, A.; Mitchell, O.S. Financial literacy and retirement preparedness: Evidence and implications for financial education. Bus. Econ. 2007, 42, 35-44. [CrossRef]

22. Carpenter, M. School programs aim to teach kids about money because parents don't. Pittsburgh Post-Gazette. Available online: https://archives.post-gazette.com/image/96551396 (accessed on 1 March 2019).

23. Green, A. Push for financial literacy spreads to schools. Christ. Sci. Monit. 2009, 101, 13.

24. Lusardi, A.; Mitchell, O.S. Financial literacy and retirement planning in the United States. J. Pension Econ. Financ. 2011, 10, 509-525. [CrossRef]

25. Lusardi, A.; Scheresberg, C. Financial literacy and high-cost borrowing in the United States; NBER Working Papers; National Bureau of Economic Research: Cambridge, MA, USA, 2013; Volume 2, pp. 1-41.

26. Mandell, L. The Financial Literacy of Young American Adults: Results of 2008 National Jump \$ Start Coalition Survey of High School Seniors and College Students; Jumpstart Colation: Washington, DC, USA, 2008; pp. 1-243.

27. Kadlec, D. Why We Want but Can't Have Personal Finance in Schools. TIME. Available online: http://business. time.com/2013/10/10/why-we-want-but-cant-have-personal-finance-in-schools/ (accessed on 1 March 2019).

28. Walstad, W. Economics education in U.S. high schools. J. Econ. Perspect. 2001, 15, 195-210. [CrossRef] 
29. Finkelstein, N.; Hanson, T.; Huang, C.; Hirschman, B.; Huang, M. Effects of Problem Based Economics on High School Economics Instruction; US Department of Education: Washington, DC, USA, 2011; pp. 1-102.

30. Atchley, R.C. Educating the public about personal finance: A call for action. J. Financ. Serv. Prof. 1998, 52, $28-32$.

31. Blue, L.; Grootenboer, P.; Brimble, M. Financial literacy education in the curriculum: Making the grade or missing the mark? Int. Rev. Econ. Educ. 2014, 16, 51-62. [CrossRef]

32. Way, W.L.; Holden, K.C. Teachers' background and capacity to teach personal finance: Results of a national study. J. Financ. Couns. Plan. 2009, 20, 64-78.

33. Gundmunson, C.G.; Zuiker, V.S.; Katras, M.J.; Sabri, M.F. Enhancing personal and family finance courses using case studies. Coll. Stud. J. 2015, 49, 321-330.

34. Haynes, D.; Chinadle, N. Private sector/educator collaboration: Project improves financial, economic literacy of America's youth. J. Fam. Consum. Sci. 2007, 99, 8-10.

35. Mandell, L.; Klein, L. The impact of financial literacy education on subsequent financial behavior. J. Financ. Couns. Plan. 2009, 20, 15-24.

36. Walstad, W.B.; Salemi, M.K. Results from a faculty development program in teaching economics. J. Econ. Educ. 2011, 42, 283-293. [CrossRef]

37. Totenhagen, C.; Casper, D.; Faber, K.; Bosch, L.; Wiggs, C.; Borden, L. Youth financial literacy: A review of key considerations and promising delivery methods. J. Fam. Econ. Issues 2015, 36, 167. [CrossRef]

38. Miller, D.; Hite, N.G.; Slocombe, T.; Railsback, B. Student Perspectives toward key personal finance variables. Delta Pi Epsil. J. 2010, 52, 168-181.

39. Mandell, L.; Klein, L.S. Motivation and financial literacy. Financ. Serv. Rev. 2007, 16, 105-116.

40. The 2016 National State of Financial \& Economic Education. Available online: http://www.surveyofthestates. com/\#situation-1 (accessed on 3 March 2019).

41. McCormick, M. The effectiveness of youth financial education: A review of the literature. J. Financ. Couns. Plan. 2009, 20, 70-83.

42. Starting Younger: Evidence Supporting the Effectiveness of Personal Finance Education for Pre-High School Students. Available online: http://www.nationaltheatre.com/ntccom/pdfs/financialliteracy.pdf (accessed on 3 March 2019).

43. Godfrey, N.S. Making our students smart about money. Educ. Dig. 2006, 71, 21-26.

44. Chen, W.; Heath, J.A. The efficacy of financial education in the early grades: Results from a statewide program. In Reframing Financial Literacy: Exploring the Value of Social Currency; Lucey, T., Lucey, J., Eds.; Information Age Publishing, Inc.: Charlotte, NC, USA, 2012; pp. 189-208.

45. Amagir, A.; Groot, W.; Maassen van den Brink, H.; Wilschut, A. A review of financial-literacy education programs for children and adolescents. Citizsh. Soc. Econ. Educ. 2018, 17, 56-80. [CrossRef]

46. Morton, J. The interdependence of economic and personal finance education. Soc. Educ. 2005, 69, 66-69.

47. Crowe, S.; Creswell, K.; Robertson, A.; Huby, G.; Avery, A.; Sheikh, A. The case study approach. BMC Med Res. Methodol. 2011, 11, 100-108. [CrossRef]

48. Yin, R.K. The case study crisis: Some answers. Adm. Sci. Q. 1981, 26, 58-65. [CrossRef]

49. Creswell, J. Qualitative Inquiry E Research Design: Choosing among Five Approaches, 3rd ed.; Sage: Thousand Oaks, CA, USA, 2013; pp. 1-442.

50. Charmaz, K. Constructing Grounded Theory, 2nd ed.; Sage: Thousand Oaks, CA, USA, 2014; pp. 1-379.

51. Strauss, A.L. Qualitative Analysis for Social Scientists; Cambridge University Press: New York, NY, USA, 1987; pp. 1-317.

52. Saldana, J. The Coding Manual for Qualitative Researchers, 3rd ed.; Sage: Thousand Oaks, CA, USA, 2016; pp. 1-333.

53. Smola, K.; Sutton, C. Generational differences: Revisiting generational work values for the new millennium. J. Organ. Behav. 2002, 23, 363-382. [CrossRef]

54. Taylor, P. The Next America: Boomers, Millennials, and the Looming Generational Showdown; Public Affairs: New York, NY, USA, 2014; pp. 1-345.

55. Walstad, W.; Urban, C.; Asarta, C.; Breitbach, E.; Bosshard, W.; Heath, J.; O’Neill, B.; Wagner, J.; Xio, J. Perspectives on evaluation in financial education: Landscape, issues, and studies. J. Econ. Educ. 2017, 48, 93-112. [CrossRef]

56. Walstad, W.; Rebeck, K. The test of financial literacy: Development and measurement characteristics. J. Econ. Educ. 2017, 48, 113-122. [CrossRef] 
57. Financial Fitness for Life. Available online: http://fffl.councilforeconed.org/ (accessed on 4 March 2019).

58. Batty, M.; Collins, J.M.; Odders-White, E. Experimental evidence on the effects of financial education on elementary school students' knowledge, behavior, and attitudes. J. Consum. Aff. 2015, 49, 69-96. [CrossRef]

59. National Endowment for Financial Education. Available online: https://www.nefe.org/What-We-Do (accessed on 5 March 2019).

60. Suiter, M.C.; Wolla, S.A. Considering the times: Resources for teaching economic and financial literacy in light of the great recession. Soc. Educ. 2015, 79, 74-77.

61. Jacob, K. Evaluating Your Financial Literacy Program: A Practical Guide; Woodstock Institute: Chicago, IL, USA, 2002; pp. 1-19.

(C) 2019 by the authors. Licensee MDPI, Basel, Switzerland. This article is an open access article distributed under the terms and conditions of the Creative Commons Attribution (CC BY) license (http://creativecommons.org/licenses/by/4.0/). 